\title{
SPECIFIČNOSTI ANALIZE FINANCIJSKIH IZVJEŠTAJA PRORAČUNSKIH KORISNIKA
}

\author{
SPECIFICS OF THE BUDGETARY USERS FINANCIAL \\ STATEMENT ANALYSIS
}

SAŽETAK: Analiza financijskih izvještaja različitih sektora i djelatnosti zahtijeva uvažavanje njihovih specifičnosti. Ta problematika je posebno istaknuta kod subjekata čiji se računovodstveni sustavi, računovodstveni standardi i načela financijskog izvještavanja međusobno razlikuju. Pored različitosti u računovodstvenom tretmanu poslovnih događaja, proračunski korisnici i subjekti drugih sektora razlikuju se i u kontekstu temeljnih ciljeva postojanja. U tome smislu neupitna je nemogućnost primjene financijskih pokazatelja oblikovanih za poduzeća realnog sektora za ocjenu djelovanja proračunskih korisnika. Pri provedbi analize financijskih izvještaja proračunskih korisnika neophodno je uvažavanje činjenice da je njihovo djelovanje usmjereno namjenskom trošenju proračunskih sredstava koje mora biti zasnovano na konceptima učinkovitosti, odgovornosti, transparentnosti i integritetu. Računovodstvo i financijsko izvještavanje proračunskih korisnika temelji se na modificiranoj obračunskoj računovodstvenoj osnovi zbog čega je neophodno oblikovanje prilagođenih financijskih pokazatelja kojima se mogu ocjenjivati ključni aspekti djelovanja proračunskih korisnika. Temeljem pregleda postojećih pristupa i indikatora analize djelovanja proračunskih korisnika na svjetskoj razini i uvažavanjem specifičnosti proračunskog računovodstva u Hrvatskoj, cilj rada je dati prijedlog mogućih financijskih pokazatelja kojima će se na temelju informacija iz temeljnih financijskih izvještaja moći ocijeniti učinkovitost, ekonomičnost, djelotvornost i svrhovitost djelovanja proračunskih korisnika.

KLJUČNE RIJEČI: analiza financijskih izvještaja, financijski pokazatelji, proračunsko računovodstvo, modificirana računovodstvena osnova, učinkovitost, ekonomičnost, djelotvornost, svrhovitost, odgovornost, transparentnost, integritet, upravljanje proračunom.

SUMMARY: When analysing financial statements, it is necessary to take into account the fact that every sector and business activity demands certain operational specifics.

Doc. dr. sc. Ana Ježovita, Sveučilište u Zagrebu, Ekonomski fakultet, Katedra za računovodstvo, Trg J. F. Kennedyja 6, HR-10000 Zagreb, Hrvatska, e-mail: ajezovita@efzg.hr 
That problem is especially emphasized in case of diverse accounting systems, financial reporting standards and principles. Budgetary users and entities of other sectors are significantly diverse in the sense of fundamental objectives of their existence. Considering that, it is unquestionable that financial ratios developed for profit sector entities are not applicable for assessment of budgetary users. Considering the specifics of budgetary users, it is essential to consider the fact that their objectives are directed to the appropriate allocation of budgetary sources that has to be connived on the principles of performance, accountability, transparency, and integrity. In addition to that, accounting and financial reporting of budgetary users is based on the modified accrual accounting basis. In that context, it is necessary to design customized financial ratios that could be used to evaluate key aspects of budgetary users.

KEY WORDS: financial statement analysis, financial ratios, budgetary accounting, modified accrual accounting basis, performance, economy, efficiency, effectiveness, accountability, transparency, integrity, budgetary management.

\section{UVOD}

Poslovanje poduzeća realnoga sektora usmjereno je stvaranju dodane vrijednosti za vlasnike. Mjerenje učinkovitosti ostvarivanja ciljeva uključuje različite tehnike, postupke i alate. Jedan od korištenijih načina mjerenja učinkovitosti je primjena instrumenata analize financijskih izvještaja, a u okviru kojih središnje mjesto pripada financijskim pokazateljima. S obzirom da se temelje na javno dostupnim podacima raspoloživih iz godišnjih financijskih izvještaja, financijski pokazatelji predstavljaju alat koji mogu primjenjivati sve interesno-utjecajne skupine, tj. i interni i eksterni korisnici. Za razliku od profitno orijentiranih poduzeća, temeljni cilj djelovanja proračunskih korisnika je učinkovito, odgovorno i transparentno trošenje proračunskih sredstava. Pored toga, računovodstveni sustav i financijsko izvještavanje u značajnoj se mjeri razlikuju kod proračunskih korisnika u odnosu na poduzeća realnog sektora. Uvažavajući navedene specifičnosti jasno je da se instrumentarij oblikovan i namijenjen ocjeni financijskog položaja i uspješnosti poslovanja poduzeća realnog sektora ne može jednoobrazno primijeniti na proračunske korisnike. Prema tome, radi provedbe smislene analize koja će rezultirati značajnim ishodima potrebno je oblikovati zaseban set financijskih pokazatelja koji će biti usmjereni specifičnim ciljevima i kriterijima djelovanja proračunskih korisnika.

\section{UČINKOVITOST, ODGOVORNOST, TRANSPARENTNOST I INTEGRITET DJELOVANJA PRORAČUNSKIH KORISNIKA KAO OSNOVA SUVREMENOG UPRAVLJANJA PRORAČUNOM}

Svaka zemlja ima javnu upravu - subjekte koji osiguravaju funkcioniranje države na općoj i lokalnoj razni. U tome kontekstu podrazumijeva se da su subjekti javne uprave proračunski korisnici koji su obveznici primjene proračunskog računovodstva. Proračunski korisnici obveznici su uspostavljanja sustava internih kontrola i predmetom su državne re- 
vizije, dok je određeni broj proračunskih korisnika obveznik uspostavljanja interne revizije (Zakon o sustavu unutarnjih kontrola u javnom sektoru, Narodne novine, broj 78/2015., članak 3.; Zakon o državnom uredu za reviziju, Narodne novine, broj 80/2011., članak 6.; Pravilnik o unutarnjoj reviziji u javnom sektoru, Narodne novine, broj 42/2016., članak 3.). Cilj subjekata javne uprave uključuje učinkovito, odgovorno i transparentno trošenje javnih (proračunskih) sredstava u za to namijenjene svrhe. Tako određeni cilj javne uprave podrazumijeva suvremeni pristup upravljanja proračunom (engl. modern budgetary governance). Upravljanje proračunom uključuje ,procese, regulativu, strukture i institucije koje su neophodne za ostvarivanje ciljeva proračunskog sustava na svrhovit, održiv i trajan način“ (OECD, 2015, str. 5.). Pored navedenoga, veliku važnost u suvremenom konceptu upravljanja u javnoj upravi ima integritet. „Stupovi suvremenog upravljanja proračunom (engl. pillars of modern public governance) uključuju planiranje proračuna utemeljeno na mehanizmima transparentnosti, integriteta, otvorenosti, sudjelovanja, odgovornosti i strateškog pristupa planiranju i ostvarivanju nacionalnih ciljeva.“ (OECD, 2017b, str. 9.)

Javna uprava mora djelovati u skladu s načelom učinkovitosti (engl. performance) što podrazumijeva ekonomičnost (engl. economy), djelotvornost (engl. efficiency) i svrhovitost (engl. effectiveness) ${ }^{1}$ u svim aktivnostima te kontinuirano jačanje odgovornosti i transparentnosti. Prema konceptu odgovornosti (engl. accountability) državni službenici odgovorni su za svrhovitu i djelotvornu raspodjelu proračunskih sredstava (OECD, 2017b, str. 9.). „Načelo ekonomičnosti podrazumijeva svođenje troškova resursa na najmanju moguću mjeru. Korišteni resursi trebaju biti na raspolaganju pravodobno, u odgovarajućoj količini i uz odgovarajuću kvalitetu te po najboljoj cijeni. Načelo djelotvornosti podrazumijeva najbolje moguće iskorištavanje raspoloživih resursa. Vezano je uz odnos korištenih resursa i izlaznih vrijednosti ostvarenih u pogledu količine, kvalitete i rokova. Načelo svrhovitosti odnosi se na ispunjavanje postavljenih ciljeva i postizanje predviđenih rezultata." (INTOSAI, web, prijevod na hrvatski, str. 3.) Naglasak u suvremenom upravljanju proračunom stavlja se na transparentnost proračuna koja se ostvaruje potpunom otvorenošću prema građanima o tome kako je novac prikupljen i na koji način potrošen, a što uključuje jasnost, sveobuhvatnost, pouzdanost, pravovremenost i dostupnost izvještaja (OECD, 2017b, str. 9.). Hrvatski Institut za javne financije transparentnost proračuna opisuje kao sustavno, potpuno i pravovremeno objavljivanje svih relevantnih fiskalnih informacija (IJF, web). Prema Organizaciji za ekonomsku suradnju i razvoj (engl. The Organisation for Economic Co-operation and Development-OECD) transparentnost proračuna osigurava odgovornost, integritet, uključenost, povjerenje i kvalitetu. Suvremeni pristup uključuje javni integritet kao strateški i održiv odgovor na korupciju. (OECD, 2017a, web) „Javni integritet se odnosi na dosljedno usklađivanje i pridržavanje zajedničkih etičkih vrijednosti, načela i normi, održavanje i stavljanje prioriteta javnih nad privatnim interesima u javnom sektoru.“ (OECD, 2017a, web) Prema OECD-u javni integritet uključuje sustav, kulturu i odgovornost, a odgovornost se sastoji od upravljanja rizicima, izvršenja, nadzora, sudjelovanja vođeno transparentnim i otvorenim upravljanjem. Kvaliteta i integritet ostvaruju se računovodstvenim standardima, sustavom internih kontrola, revizijom i nadzorom (IJF, web).

Navedeni prijevodi pojmova preuzeti su iz službenog prijevoda Međunarodnih standarda vrhovnih revizijskih institucija (ISSAI) Državnog ureda za reviziju. 
Javni sektor u Republici Hrvatskoj sastoji se od opće države i javnih poduzeća. Javna poduzeća ${ }^{2}$ su ona rezidentna poduzeća u kojima državne strukture ili druga javna poduzeća imaju prevladavajuću kontrolu (IMF, 2014, str. 27.). Opća država ili javna uprava uključuju središnju državnu, regionalnu vlast i lokalnu vlast. U Republici Hrvatskoj ukupno je 3.715 (Ministarstvo financija, web) proračunskih i izvanproračunskih korisnika koji sačinjavaju opću državu, a uključuju (Bejaković, P., Vukšić, G. i Bratić V., 2011., str. 99-125.):

- središnju državu:

- proračunski korisnici državnog proračuna (643 obveznika)

- izvanproračunski korisnici državnog proračuna (8 obveznika)

- regionalnu i lokalnu vlast:

- proračunski korisnici proračuna jedinica lokalne i područne (regionalne) samouprave (3044 obveznika)

- izvanproračunski korisnici jedinica lokalne i područne (regionalne) samouprave (20 obveznika).

Prema Zakonu o proračunu proračunskim se korisnicima smatraju ona tijela, ustanove, jedinice i vijeća čiji se rashodi financiraju iz proračunskih sredstava (Zakon o proračunu, Narodne novine, broj 87/2008., 136/2012., 15/2015., članak 3.). Za razliku od proračunskih korisnika, izvanproračunski korisnici državnog proračuna se pored sredstava iz proračuna financiraju i iz namjenskih prihoda te imaju veći stupanj autonomije u odlučivanju o raspodijeli prihoda i rashoda (IJF, web).

Proračunski korisnici obveznici su primjene proračunskog računovodstva (Pravilnik o proračunskom računovodstvu i računskom planu, Narodne novine, broj 124/2014., 115/2015., 87/2016., 3/2018.). Proračunsko računovodstvo je specifični sustav evidentiranja poslovnih događaja, njihove analize i financijskog izvještavanja djelovanja proračunskih i izvanproračunskih korisnika (Zakon o proračunu, Narodne novine broj 87/2008., 136/2012., 15/2015., članak 3.). Osim na načelima točnosti, istinitosti, pouzdanosti i pojedinačnom iskazivanju poslovnih događaja te Međunarodnim računovodstvenim standardima za javni sektor (engl. International Public Sector Accounting Standards - IPSAS) proračunsko računovodstvo u Republici Hrvatskoj temelji se i na modificiranoj računovodstvenoj osnovi nastanka događaja. Temeljna razlika modificirane u odnosu na obračunsku osnovu je trenutak priznavanja prihoda. U skladu s modificiranom novčanom osnovom prihodi se priznaju onda kada su naplaćeni, a ne kada je poslovni događaj nastao, dok se rashodi priznaju prema načelu nastanka poslovnog događaja, ali se trošak nabave priznaje kao rashod u trenutku nabave, a ne stvarnog utroška ${ }^{3}$ (Pravilnik o proračunskom računovodstvu i računskom planu, Narodne novine, broj 124/2014., 115/2015., 87/2016., 3/2018., članak 20.). Prema modificiranoj računovodstvenoj osnovi ne iskazuje se rashod od amortizacije te prihodi i rashodi uslijed promjena vrijednosti nefinancijske imovine (Pravilnik o proračunskom računovodstvu i računskom planu, Narodne novine, broj 124/2014., 115/2015., 87/2016., 3/2018., članak 20.). Nastavno na specifičnosti proračunskog računovodstva, pro-

\footnotetext{
2 Prema podacima Ministarstva financija u 2016. godini ukupno je bilo 55 javnih poduzeća za koja su javno objavljeni godišnji financijski izvještaji.

Uz iznimku u obavljanju vlastite trgovačke i proizvođačke djelatnosti u zdravstvu gdje se rashodi priznaju u trenutku prodaje.
} 
računski korisnici financijske izvještaje sastavljaju prema Pravilniku o financijskom izvještavanju prilagođenom specifičnostima proračunskog računovodstva.

\section{PREGLED LITERATURE I DOSADAŠNJIH ISTRAŽIVANJA O FINANCIJSKIM POKAZATELJIMA ZA SUBJEKTE JAVNE UPRAVE}

Najveći broj poznatih financijskih pokazatelja razvijen je za profitna poduzeća realnog sektora, a postoje i specifični pokazatelji za analizu poslovanja banaka i osiguravajućih društava (Žager, K., Mamić Sačer, I., Sever Mališ, S., Ježovita, A. i Žager, L., 2017.). Određeni autori na svjetskoj razini i u Hrvatskoj bavili su se pitanjem analize financijskih izvještaja javnog sektora i u sklopu toga proračunskih korisnika.

Nekoliko je važnih objava i radova na svjetskoj razini povezano s analizom proračunskih korisnika primjenom pokazatelja (tablica 2.). U kontekstu danog pregleda pokazatelja važno je razumjeti pojmove pokazatelj i financijski pokazatelj. Financijski pokazatelj predstavlja omjer najmanje dviju financijskih vrijednosti odnosno podataka dostupnih iz financijskih izvještaja ili računovodstvenih sustava subjekata. Pokazatelj predstavlja podatak kao broj ne ograničavajući se na financijske podatke. Značajan broj predstavljenih pokazatelja pored financijskih informacija zahtijevaju i druge nefinancijske kvantitativne informacije, primjerice broj stanovnika, a određeni dio predstavljenih pokazatelja predstavlja apsolutnu vrijednost.

Jedan od prvih autora koji se bavio tim područjem je Brown (1993.) koji je oblikovao deset ključnih pokazatelja financijskog stanja subjekata u javnom sektoru. Važno je istaknuti da je općeprihvaćenim računovodstvenim standardima subjekata javnog sektora upravo pojam financijsko stanje stavljen u prvi plan. Kanadski institut ovlaštenih računovođa definira financijsko stanje (engl. financial condition) kao ,financijsko zdravlje upravljačkog tijela javnog sektora koje je mjereno održivosti, osjetljivosti i fleksibilnosti, promatrano $\mathrm{s}$ aspekta ukupnog ekonomskog i financijskog okruženja“ (CICA, web). Prema Odboru za računovodstvo javnog sektora (engl. the Public Sector Accounting Board - PSAB) održivost (engl. sustainability) mjeri sposobnost jedinice da održava postojeću razinu aktivnosti i podmirivanja dospjelih obveza bez dodatnog zaduživanja, fleksibilnost (engl. flexibility) opisuje do koje razine pojedina jedinica može promijeniti teret dugom ili povećanje poreza unutar postojeće ekonomičnosti, a osjetljivost (engl. vulnerability) mjeri ovisnost jedinice od prihodima izvan svoje kontrole i njezinu izloženost rizicima koji mogu utjecati na sposobnost podmirenja obveza (Mead, D. M., 2001.). 
Tablica 1.: Pregled najpoznatijih pokazatelja za analizu proračunskih korisnika

\begin{tabular}{|c|c|c|c|c|}
\hline $\begin{array}{c}\text { Odbor za } \\
\text { računovodstvo } \\
\text { javnog sektora }\end{array}$ & $\begin{array}{c}\text { Kanadski institut } \\
\text { ovlaštenih } \\
\text { računovođa }\end{array}$ & \multicolumn{2}{|c|}{$\begin{array}{l}\text { Međunarodno udruženje za upravljanje } \\
\text { lokalnim i regionalnim jedinicama }\end{array}$} & $\begin{array}{l}\text { Brownov test "10 } \\
\text { bodova" }\end{array}$ \\
\hline $\begin{array}{l}\text { ODRŽIVOST } \\
\text { - Godišnji suficit } \\
\text { ili deficit } \\
\text { - Omjer financijske } \\
\text { imovine i obveza } \\
\text { - Neto dug } \\
\text { kao postotak } \\
\text { područnog BDP-a } \\
\text { - Neto dug po } \\
\text { stanovniku } \\
\text { FLEKSIBILNOST } \\
\text { - Troškovi } \\
\text { servisiranja obveza } \\
\text { kao postotak } \\
\text { prihoda } \\
\text { - Vlastiti prihodi } \\
\text { kao postotak } \\
\text { područnog BDP-a } \\
\text { OSJETLJIVOST } \\
\text { - Prijenos središnje } \\
\text { države kao } \\
\text { postotak ukupnih } \\
\text { prihoda }\end{array}$ & $\begin{array}{l}\text { ODRŽIVOST } \\
\text { - Neto dug kao } \\
\text { postotak BDP-a } \\
\text { - Promjena neto } \\
\text { duga i BDP-a } \\
\text { FLEKSIBILNOST } \\
\text { - Troškovi } \\
\text { servisiranja javnog } \\
\text { duga kao postotak } \\
\text { ukupnih prihoda } \\
\text { - Vlastiti prihodi } \\
\text { kao postotak } \\
\text { BDP-a } \\
\text { OSJETLJIVOST } \\
\text { - Prijenos središnje } \\
\text { države kao } \\
\text { postotak ukupnih } \\
\text { prihoda } \\
\text { - Dug u stranoj } \\
\text { valuti kao postotak } \\
\text { ukupnog duga za } \\
\text { područnu namjenu }\end{array}$ & $\begin{array}{l}\text { PRIHODI } \\
\text { Prihodi po stanovniku } \\
\text { Ograničeni prihodi } \\
\text { Međuvladini prihodi } \\
\text { Prihodi od elastičnih } \\
\text { poreza } \\
\text { Jednokratni prihodi } \\
\text { Prihodi od poreza na } \\
\text { imovinu } \\
\text { Nenaplaćeni prihod od } \\
\text { poreza na imovinu } \\
\text { Pokrivenost naknada } \\
\text { Nedostaci prihoda } \\
\text { RASHODI } \\
\text { Rashodi po stanovniku } \\
\text { Zaposleni po stanovniku } \\
\text { Fiksni troškovi } \\
\text { Povlastice } \\
\text { Operativni rashodi } \\
\text { NEKAPITALIZIRANE } \\
\text { OBVEZE } \\
\text { Nekapitalizirane obveze } \\
\text { za mirovine } \\
\text { Mirovinska imovina } \\
\text { Akumulirani dopust } \\
\text { zaposlenika }\end{array}$ & $\begin{array}{l}\text { OPERATIVNI } \\
\text { POLOŽAJ } \\
\text { Operativni deficit } \\
\text { Gubici/dobici } \\
\text { subjekta } \\
\text { Ravnoteža fonda } \\
\text { Likvidnost } \\
\text { Kratkoročne } \\
\text { obveze } \\
\text { Dugoročni dug } \\
\text { Dug usluga } \\
\text { Preklapanje duga } \\
\text { Amortizacija duga } \\
\text { Kratkoročni dug } \\
\text { KAPITALNI } \\
\text { POGON } \\
\text { Ulaganje u } \\
\text { održavanje } \\
\text { Kapitalna ulaganja } \\
\text { Rashodi } \\
\text { amortizacije } \\
\text { POTREBE } \\
\text { I RESURSI } \\
\text { ZAJEDNICE } \\
\text { nefinancijski } \\
\text { pokazatelji }\end{array}$ & $\begin{array}{l}\text { Ukupni prihodi / } \\
\text { Broj stanovnika } \\
\text { Ukupni prihodi } \\
\text { općeg fonda iz } \\
\text { vlastitih izvora / } \\
\text { Ukupni prihodi } \\
\text { općeg fonda } \\
\text { Izvori općeg fonda } \\
\text { iz drugih fondova } \\
\text { / Ukupni izvori } \\
\text { općeg fonda } \\
\text { Operativni rashodi } \\
\text { / Ukupni rashodi } \\
\text { Nerezervirana } \\
\text { ravnoteža općeg } \\
\text { fonda / Ukupni } \\
\text { prihodi općeg } \\
\text { fonda } \\
\text { Ukupan novac i } \\
\text { investicije općeg } \\
\text { fonda / Ukupne } \\
\text { obveze općeg fonda } \\
\text { Izravni dugoročni } \\
\text { dug / Broj } \\
\text { stanovnika } \\
\text { Dug od usluga / } \\
\text { Ukupni prihodi }\end{array}$ \\
\hline
\end{tabular}

Izvor: PSAB, 2010; CICA, 1997; ICMA, 2003; Brown, K. W., 1993.

U literaturi se razlikuju pojmovi financijskog položaja (engl. financial position) i financijskog stanja (engl. financial condition) u smislu da financijski položaj predstavlja kratkoročniju ocjenu od financijskog stanja, a financijsko stanje uključuje ocjenu vjerojatnosti da će subjekt moći pravovremeno podmirivati sve svoje obveze, što se mjeri novčanom solventnošću, proračunskom solventnošću, dugoročnom solventnošću i solventnošću na razini usluga, dok s treće strane ekonomsko stanje (engl. economic condition) predstavlja financijsko zdravlje, sposobnost i volju za podmirivanje obveza kao i odanost pružanju usluga uključujući tri komponente - financijsko stanje, fiskalne kapacitete i uslužne kapacitete (Reck, J., Lowensohn, S. i Wilson, E., 2016., str. 409-410.).

Brown (1993.) opisuje kratak test financijskog stanja koji se može provesti za općine koje imaju do 100.000 stanovnika, a temeljem usporedbe rezultata sa sličnim općinama oblikuje se konačna ocjena (Brown, K. W., 1993., str. 21.). Zbog relativno malo znanja o važnosti i značaju pojedinog pokazatelja svakom se dodjeljuje jednaka važnost, a bodovi se dodjeljuju temeljem dobivenih rezultata pri čemu zbroj bodova svih pokazatelja daje ukupnu ocjenu u odnosu na druge gradove i općine dostupne u bazi (Brown, K. W., 1993., 
str. 24.). Kanadski institut ovlaštenih računovođa (engl. the Canadian Institute of Chartered Accountants - CICA) 1997. godine objavljuje pokazatelje za ocjenu financijskog stanja subjekata u javnom sektoru podijeljene u tri skupine pokazatelja: održivost, fleksibilnost i osjetljivost, što je u skladu s njihovom definicijom financijskog stanja. Istu podjelu pokazatelja koristi i Odbor za računovodstvo javnog sektora (engl. the Public Sector Accounting Board - PSAB), koji pokazatelje podijeljene u iste tri skupine objavljuje u četvrtoj izjavi preporučene prakse (engl. SORP 4: Indicators of Financial Condition). Detaljniju razradu pokazatelja objavljuje Međunarodno udruženje za upravljanje lokalnim i regionalnim jedinicama (engl. International City/County Management Association's - ICMA) u svome priručniku namijenjenom lokalnim razinama upravljanja. Pored navedenih, svoj doprinos daje i Odbor za računovodstvene standarde u javnom sektoru (engl. Government Accounting Standards Board - GASB) u priručniku Vodič analitičara o financijskim izvještajima javnog sektora (engl. An Analyst's Guide to Government Financial Statements) kojega je pripremio Dean Michael Mead 2001. godine. Većina znanstvenih radova o primjeni pokazatelja vezana je za ocjenu financijskog stanja i vodi se ranije istaknutim predloženim pokazateljima uz određene modifikacije ovisno o cilju rada.

Kablan (2013.) u svom radu provodi analizu financijskih izvještaja na primjeru proračunskog korisnika na lokalnoj razini (općina Beylikdüzü). Cilj provedenoga istraživanja je potvrđivanje da je tehnike analize moguće jednako primijeniti na proračunske korisnike kao što ih primjenjuju poduzeća profitnog sektora i u tome smislu stvarati informacije važne u kontekstu unapređenja sustava financijskih kontrola (Kablan, A., 2013., str. 75-86.). „Svrha javnih institucija razlikuje se od svrhe poduzeća u privatnom sektoru. Dok je svrha poduzeća privatnog sektora maksimizacija dobiti, svrha javnih institucija je omogućiti učinkovito, produktivno i ekonomično korištenje resursa i usluga za društvo u cjelini.“ (Kablan, A., 2013., str. 75-86) Autor ističe da su se pitanjem oblikovanja financijskih pokazatelja u pravilu dosada bavila profesionalna udruženja na području javnog sektora.

Suarez, Lesneski i Denison (2011.) na primjeru lokalnih zdravstvenih ustanova naglašavaju važnost primjene pokazatelja u kontekstu ocjene usklađenosti rashoda s misijom, ciljevima, izvedbom, usporedbu sa sličnim jedinicama, stvaranje informativne podloge za okvir financijskih standarda, sposobnost za oblikovanja obrazaca trošenja s ciljem uspostavljanja kvalitetnije politike upravljanja sredstvima (Suarez, V., Lesneski, C. i Denison, D., 2011., str. 422-423.). Autori su pokazatelje grupirali u četiri skupine: pokazatelji prihoda, pokazatelji rashoda, pokazatelji kritičnih projekata i statistika zajednice.

Ramsey (2013.) u svome radu daje pregled najčešce korištenih pokazatelja oblikovanih od strane različitih autora. Temeljem cjelokupnog pregleda literature na svjetskoj razini moguće je izdvojiti nekoliko pokazatelja koji se pojavljuju kod većine autora. U najvećem broju slučajeva radi se o pokazateljima vezanim za prikupljene prihode i rashode djelovanja subjekata javnog sektora. Kao važan pokazatelj istaknut je omjer ukupnih prihoda i broja stanovnika koji daje informaciju o prihodima po stanovniku za promatranog proračunskog korisnika (Ramsey, T. K., 2013., str. 8-9.). Nadalje, značajnima se čine pokazatelji koji su u svome izračunu vezani za neki aspekt obveza subjekta te općenito pokazatelji vezani za namjenu rashoda.

U Hrvatskoj postoji nekoliko radova na temu pokazatelja subjekata javnog sektora, a u potpunosti se povezuju s indikatorima predstavljenim i korištenim na svjetskoj razini. Roje (2008.) je istražila problematiku standardizacije pokazatelja za ocjenu financijskog položaja 
proračunskih korisnika u zemljama Sjeverne Amerike i Australije. Autorica kao preduvjet mjerenja financijskog položaja države naglašava nužnost sveobuhvatnosti u priznavanju poslovnih događaja uvođenjem obračunske osnove u računovodstvo i financijsko izvještavanje proračunskih korisnika (Roje, G., 2008., str. 28-31,). „Sukladno iskustvima razvijenih zemalja navedenim u ovome radu, poticanje prakse kontinuirane procjene financijskog položaja države i državnih jedinica drži se sastavnicom reforme državnog računovodstva i usmjereno je prema sljedećim glavnim ciljevima: (1) poticanju usporedivosti financijskog izvještavanja u javnom sektoru (razumijevanje iskaza o javnoj potrošnji i državnim resursima) i (2) prikupljanju informacija o: promjeni ekonomskog i financijskog položaja države u određenom vremenskom razdoblju, sposobnosti države u podmirivanju postojećih financijskih obveza, kako u pogledu generiranja dodatnih prihoda, tako i u pogledu mogućnosti daljnjeg zaduživanja za zadovoljavanje javnih potreba.“ (Roje, G., 2008., str. 28-31,) U radu je dan pregled pokazatelja Kanadskog instituta ovlaštenih računovođa (engl. Canadian Institute of Charted Accountants - PSAB) koji ih dijele na pokazatelje održivosti, fleksibilnosti i osjetljivosti.

Sever i Žager (2008.) naglašavaju važnost provedbe analize financijskih izvještaja kao instrumenta kontrole u javnom sektoru. Radom su istaknute mogućnosti i ograničenja primjene postojećeg seta financijskih pokazatelja kod različitih subjekata javnog sektora kao što su proračunski korisnici, javna poduzeća i neprofitne organizacije. „Određene razlike mogu se očekivati u pokazateljima profitabilnosti s obzirom na činjenicu da je poslovanje ovih subjekata uvelike ovisno o smjernicama ekonomske i fiskalne politike kao i o činjenici da se cijena proizvoda i usluga koje ta poduzeća nude na tržištu ne određuje uvijek pod tržišnim uvjetima. Ograničenja analize financijskih izvještaja proračunskih korisnika proizlaze iz činjenice da nema dobiti (profita kao cilja).“ (Sever, S. i Žager, L., 2008., str. 439.) Autori naglašavaju kako su struktura i sadržaj financijskih izvještaja, kao i rezultat poslovanja različitih subjekata javnog sektora različiti uslijed primjene različite računovodstvene osnove, što predstavlja opravdanu potrebu provedbe analize usklađene sa specifičnostima pojedinih subjekata. „Financijskim pokazateljima upravo se naglašava potreba za racionalnošću, što znači da je njihova primjena, uz određena ograničenja, opravdana i u javnom sektoru. Osim toga, analitički postupci, tj. instrumenti i postupci analize financijskih izvještaja, mogu poslužiti i kao instrumenti kontrole unutarnje revizije u javnom sektoru.“ (Sever, S. i Žager, L., 2008., str. 443.)

Hladika i Žigman (2012.) bave se pitanjem ocjene djelovanja neprofitnih organizacija primjenom financijskih pokazatelja. Financijsko izvještavanje neprofitnih organizacija razlikuje se od izvještavanja proračunskih korisnika, ali mu je bliže od računovodstvenog sustava i financijskog izvještavanja poduzeća u realnom sektoru. U kontekstu primjene dobivenih rezultata važno je istaknuti različite ciljeve djelovanja proračunskih korisnika od neprofitnih organizacija pa je time naglašena važnost oblikovanja specifičnog seta pokazatelja koji će isticati ciljeve proračunskih korisnika. „Prikazani su samo odabrani financijski pokazatelji zbog nemogućnosti primjene nekih zbog razlika u raspoređivanju računovodstvenih kategorija. Problem koji se javlja jest nepostojanje graničnih vrijednosti za navedene financijske pokazatelje koje bi ukazale zadovoljava li organizacija postavljeni kriterij ili ne, kao i smislenost pokazatelja koji se mogu izračunati.“ (Hladika, M. i Žigman, A., 2012., str. 29.) Autorice su u radu prikazale način izračuna odabranih financijskih pokazatelja za neprofitne organizacije koje su sistematizirale na temelju Abraham (2004.), Abraham (2006.) i Holman (2012.) (Hladika, M. i Žigman, A., 2012., str. 28-29,). 


\section{OBLIKOVANJE FINANCIJSKIH POKAZATELJA ZA PRORAČUNSKE KORISNIKE U REPUBLICI HRVATSKOJ}

Prethodno predočenim pregledom literature dan je pregled mogućih pokazatelja za ocjenu financijskog stanja subjekta u javnom sektoru. Radi se o pokazateljima koji su prije svega prilagođeni specifičnostima javnog sektora anglosaksonskih zemalja. Veliki broj pokazatelja za izračun, pored informacija iz temeljnih financijskih izvještaja, zahtijeva dodane nefinancijske kvantitativne informacije kao što su broj stanovnika, broj zaposlenih, razina bruto društvenog proizvoda i slično. Bitno je naglasiti i to da su razlike u računovodstvenim sustavima i financijskom izvještavanju subjekata javnog sektora na svjetskoj razini izraženije nego kod nekih drugih subjekata te u tome smislu postoje ograničenja njihove primjene kod proračunskih korisnika u Republici Hrvatskoj. Dodatno ograničenje je što većina literature ne precizira kojim subjektima javnog sektora su namijenjeni pokazatelji, ali je pretpostavka da se u većini slučajeva radi upravo o proračunskim korisnicima koji su predmetom ovoga rada. Konačno, iako proračunski korisnici predstavljaju specifične subjekte kojima nije cilj maksimizacija dobiti, već su usmjereni učinkovitom, odgovornom i transparentnom trošenju javnih (proračunskih) sredstava u za to namijenjene svrhe, nezahvalno je ocjenu njihova djelovanja ograničiti isključivo na ocjenu financijskog stanja, posebice uzimajući u obzir nužnost ekonomičnosti, djelotvornosti i svrhovitosti djelovanja. Uvažavajući prethodno navedene činjenice u radu je dan prijedlog pojedinačnih financijskih pokazatelja za proračunske korisnike u Republici Hrvatskoj. Važno je istaknuti da se radi isključivo o financijskim pokazateljima za izračun kojih su potrebni podaci dostupni u financijskim izvještajima. Pokazatelji su grupirani u pet skupina kojima se ocjenjuju različiti aspekti djelovanja proračunskih korisnika, a uključuju pokazatelje ekonomičnosti, svrhovitosti, kapitalnih investicija, likvidnosti i zaduženosti. Može se reći da se pokazatelji ekonomičnosti i svrhovitosti mogu koristiti za ocjenu učinkovitosti proračunskih korisnika, a pokazatelji kapitalnih investicija, likvidnosti i zaduženosti mogu se smatrati pokazateljima za ocjenu financijskog stanja. Radi mogućnosti stvaranja određene poveznice, gdje je moguće, nastojalo se uskladiti nazive financijskih pokazatelja s drugim sektorima, a prije svega s financijskim pokazateljima realnog sektora koji su međunarodno prepoznati (Žager, K., Mamić Sačer, I., Sever Mališ, S., Ježovita, A. i Žager, L.; 2017.; Gibson, C. H., 2011.; Palepu, K. G., Healy, P. M., Bernard, V. L. i Peek, E., 2007.; Penman, S., 2009.; Robinson, T. R., Van Greuning, H., Henry, E. i Broihahn, M. A., 2009.; Subramanyam, K. R. i Wild, J. J., 2009.; Wahlen, J. M., Baginski, S. P. i Bradshaw, M. T., 2011.). Radi lakše primjene stavkama iz financijskih izvještaja koje se koriste za izračun pojedinog financijskog pokazatelja nadodane su brojčane oznake razreda, skupine konta ili sintetičkog konta prema obveznom kontnom planu za proračunske korisnike (brojevi u tablicama u zagradama) (Pravilnik o proračunskom računovodstvu i računskom planu, Narodne novine, br. 124/2014., 115/2015., 87/2016., 3/2018.).

\subsection{Pokazatelji ekonomičnosti}

Kao što je ranije istaknuto ekonomično djelovanje uključuje svođenje rashoda na najmanju moguću mjeru te u tome smislu mjeri djelotvornost proračunskog korisnika. Pokazatelji ekonomičnosti smatraju se mjerom djelotvornosti (efikasnosti), tj. mjerom maksimi- 
zacije svrhovitog raspoređivanja prihoda. Svrhovitost označava djelovanje na način prema kojem se ispunjavaju ciljevi proračunskog korisnika. Prema tome može se reći da svrhovito djelovanje označava ispunjavanje ciljeva, a djelotvornost maksimizaciju iskorištavanja raspoloživih prihoda. Proračunski korisnici koji djeluju svrhovito i djelotvorno su učinkoviti. Ekonomičnost je moguće mjeriti prema različitim vrstama proračunskih prihoda i primitaka, rashoda i izdataka (tablica 2.).

Tablica 2. Financijski pokazatelji ekonomičnosti

\begin{tabular}{|l|l|l|}
\hline Naziv pokazatelja & Brojnik & Nazivnik \\
\hline Ekonomičnosti poslovanja & Prihodi poslovanja (6) & Rashodi poslovanja (3) \\
\hline $\begin{array}{l}\text { Ekonomičnost nabave } \\
\text { imovine }\end{array}$ & $\begin{array}{l}\text { Prihodi od prodaje } \\
\text { nefinancijske imovine (7) }\end{array}$ & $\begin{array}{l}\text { Rashodi za nabavu } \\
\text { nefinancijske imovine (4) }\end{array}$ \\
\hline $\begin{array}{l}\text { Ekonomičnost } \\
\text { financiranja }\end{array}$ & $\begin{array}{l}\text { Primici od financijske } \\
\text { imovine i zaduživanja (8) }\end{array}$ & $\begin{array}{l}\text { Izdaci za financijsku imovinu } \\
\text { i otplatu zajmova (5) }\end{array}$ \\
\hline $\begin{array}{l}\text { Ekonomičnost upravljanja } \\
\text { dugom }\end{array}$ & Primici od zaduživanja (84) & $\begin{array}{l}\text { Izdaci za otplatu glavnice } \\
\text { primljenih kredita i zajmova } \\
(54)\end{array}$ \\
\hline $\begin{array}{l}\text { Ekonomičnost prihoda i } \\
\text { rashoda }\end{array}$ & Ukupni prihodi (6 + 7) & Ukupni rashodi (3 + 4) \\
\hline $\begin{array}{l}\text { Ekonomičnost ukupnog } \\
\text { djelovanja }\end{array}$ & $\begin{array}{l}\text { Ukupni prihodi i primici } \\
(6+7+8)\end{array}$ & $\begin{array}{l}\text { Ukupni rashodi i izdaci } \\
(3+4+5)\end{array}$ \\
\hline
\end{tabular}

Izvor: izrada autora.

Ekonomičnost poslovanja financijski je pokazatelj koji se izračunava kao omjer prihoda i rashoda poslovanja odnosno onih prihoda i rashoda koji su neophodni za redovito obavljanje aktivnosti proračunskih korisnika. Može se zaključiti da je poželjno da prihodi poslovanja budu veći od rashoda poslovanja, što znači da je očekivana vrijednost pokazatelja veća od 1. Prihodi poslovanja u najvećoj se mjeri odnose na prihode od poreza, dok rashodi u najvećoj mjeri uključuju rashode za zaposlene, materijalne rashode, subvencije, pomoći i naknade. Pokazateljem ekonomičnost poslovanja mjeri se efikasnost (djelotvornost) korištenja raspoloživih prihoda poslovanja proračunskog korisnika.

Ekonomičnost nabave imovine izračunava se kao omjer prihoda od prodaje i rashoda za nabavu nefinancijske imovine, a predstavlja ocjenu djelotvornosti u prenamjeni sredstava iz jednog u drugi oblik nefinancijske imovine. Prihodi od prodaje nefinancijske imovine predstavljaju prihode koji su ostvareni prodajom neproizvedene dugotrajne imovine kao što su zemljišta i ostala prirodna bogatstva te proizvedene dugotrajne imovine koja uključuje imovinu kao što su građevinski objekti, postrojenja, transportna sredstva i slično. Ekonomičnost nabave imovine očekivano će biti manja od jedan s obzirom da su ulaganja u novu nefinancijsku imovinu poželjna i neophodna.

Ekonomičnost financiranja izračunava se kao omjer primitaka od financijske imovine i zaduživanja i izdataka za financijsku imovinu i otplatu zajmova. Primici od financijske imovine uključuju povrate glavnica danih zajmova i depozita, prodaje tuđih vrijednosnih papira te s aspekta zaduživanja, primitke na ime izdanih vrijednosnih papira i primljenih 
kredita i zajmova. Izdaci za financijsku imovinu uključuju izdatke po osnovi danih zajmova i depozita, ulaganja u tuđe vrijednosne papire te izdatke za otplate glavnice primljenih kredita i zajmova i isplate dospjelih izdanih vrijednosnih papira. Promatrano s toga aspekta češća je situacija u kojoj proračunski korisnici u većoj mjeri trebaju sredstva financiranja, nego što ih nude drugima, iako to u velikoj mjeri ovisi i o konkretnom proračunskom korisniku. Može se očekivati da će vrijednost toga pokazatelja biti manja od 1.

Ekonomičnost upravljanja dugom predstavlja omjer primitaka od zaduživanja te izdataka za otplatu glavnice primljenih kredita i zajmova u pojedinoj godini. Ako je vrijednost pokazatelja veća od jedan to znači da se proračunski korisnik u pojedinom razdoblju više dodatno zadužio nego vratio pozajmljenih sredstava i, obrnuto, ako je vrijednost pokazatelja manja od jedan. O tome kakva će biti vrijednost toga pokazatelja ovisi o raspoloživim proračunskim sredstvima za pokrivanje svih proračunskih rashoda.

Ekonomičnost prihoda i rashoda financijski je pokazatelj koji se izračunava kao omjer ukupnih prihoda i ukupnih rashoda. Ukupni prihodi uključuju prihode poslovanja i prihode od prodaje nefinancijske imovine. Ukupni rashodi uključuju rashode poslovanja i rashode za nabavu nefinancijske imovine. Iako prihodi i rashodi poslovanja predstavljaju osnovne kategorije poslovanja proračunskih korisnika, s druge strane prodaja i nabava nefinancijske imovine je neizostavni dio poslovanja većine proračunskih korisnika kojima se želi unaprijediti postojeće blagostanje građanima na području djelovanja te se u tome smislu mogu smatrati nužnim i neizostavnim dijelom redovitih aktivnosti proračunskih korisnika. Ekonomičnost prihoda i rashoda predstavlja mjeru djelotvornosti upravljanja ukupnim prihodima i rashodima proračunskog korisnika.

Ekonomičnost ukupnog djelovanja mjera je ukupne djelotvornosti proračunskih korisnika koja se izračunava kao omjer ukupnih prihoda i primitaka te ukupnih rashoda i izdataka. Za razliku od ekonomičnosti prihoda i rashoda, ekonomičnost ukupnog djelovanja uključuje i učinke financiranja. Ako je koeficijent ekonomičnosti ukupnog djelovanja veći od ekonomičnosti prihoda i rashoda tada je učinak financiranja negativan u smislu da se te godine proračunski korisnik više zadužio, nego otplatio primljenih kredita i zajmova. Vrijedi i obrnuto, ako je ekonomičnost ukupnog djelovanja manja od ekonomičnosti prihoda i rashoda, tada je u tom razdoblju proračunski korisnik više primljenih kredita i zajmova otplatio, nego primio novih. Jasno je da primici i izdaci uključuju i ulagačke učinke kupnje i prodaje tuđih vrijednosnih papira pa ih je potrebno uzeti u obzir pri interpretaciji ako oni predstavljaju značajne primitke i izdatke za proračunskog korisnika. To je moguće ocijeniti usporedbom pokazatelja ekonomičnost financiranja i ekonomičnosti upravljanja dugom. Ako je ta razlika značajna to znači da tuđi vrijednosni papiri predstavljaju značajan element toga pokazatelja, a učinak je u ovisnosti o tome ima li više primitaka ili izdataka.

\subsection{Pokazatelji svrhovitosti}

Učinkovitost proračuna pored ekonomičnosti i djelotvornosti podrazumijeva i njegovu svrhovitost. Ranije je istaknuto da svrhovitost predstavlja ostvarivanje ciljeva i postizanje predviđenih rezultata. Ostvarivanje ciljeva proračunskih korisnika uključuje adekvatno trošenje proračunskih sredstava prema njihovoj namjeni. U tome smislu, proračunski korisnik djeluje svrhovito ako raspoloživim prihodima i primicima uspije pokriti sve neophodne rashode i izdatke (tablica 4.). Navedenu skupinu pokazatelja moguće je usporediti s poka- 
zateljima profitabilnosti kod profitno orijentiranih poduzeća. Za razliku od profitno orijentiranih poduzeća koja nastoje maksimizirati zarade, proračunski korisnici nastoje ostvariti višak prihoda i primitaka koji im može osigurati daljnji razvoj. Pokazatelji svrhovitosti smatraju se mjerom učinkovitosti.

Tablica 3. Financijski pokazatelji svrhovitosti

\begin{tabular}{|l|l|l|}
\hline Naziv pokazatelja & Brojnik & Nazivnik \\
\hline Kvaliteta prihoda & Prihodi poslovanja (6) & $\begin{array}{l}\text { Ukupni prihodi i primici } \\
(6+7+8)\end{array}$ \\
\hline $\begin{array}{l}\text { Omjer poreznih } \\
\text { prihoda }\end{array}$ & $\begin{array}{l}\text { Prihodi od poreza i doprinosa } \\
(61+62)\end{array}$ & $\begin{array}{l}\text { Ukupni prihodi i primici } \\
(6+7+8)\end{array}$ \\
\hline Stopa viška/manjka & $\begin{array}{l}\text { Višak/manjak prihoda i primitaka } \\
+ \text { financijski rashod (34) }\end{array}$ & $\begin{array}{l}\text { Ukupni prihodi i primici } \\
(6+7+8)\end{array}$ \\
\hline $\begin{array}{l}\text { Omjer obračunatih i } \\
\text { naplaćenih prihoda }\end{array}$ & Obračunati prihodi $(96+97)$ & Ukupni prihodi $(6+7)$ \\
\hline
\end{tabular}

Izvor: izrada autora.

Kvalitetom prihoda koja se izračunava kao omjer prihoda poslovanja te ukupnih prihoda i primitaka mjeri se koliki dio raspoloživih prihoda dolazi iz osnovnog izvora prihoda proračunskih korisnika, tj. iz proračuna. Kao što je ranije istaknuto, prihodi poslovanja u najvećoj mjeri uključuju prihode od poreza i doprinosa, a dodano obuhvaćaju pomoći, prihode od financijske i nefinancijske imovine, prihode od upravnih i administrativnih pristojbi, pristojbi po posebnim propisima i naknada, prihode od prodaje proizvoda, roba i pruženih usluga, prihode iz nadležnosti proračuna i od HZZO-a, kazne, upravne mjere i slično. Koji će prihodi prevladati kod pojedinog proračunskog korisnika ovisi o razini proračunskog korisnika u strukturi javne uprave te radi li se o proračunskom korisniku državnog proračuna ili proračuna jedinice područne (regionalne) i lokalne samouprave ili pak o izvanproračunskom korisniku. Kod analize strukture prihoda poslovanja potrebno je voditi računa o tim specifičnostima. U tome smislu, moguće je i poželjno prilagoditi pojedine pokazatelje.

Još precizniji pokazatelj kvalitete izvora sredstava proračunskog korisnika je omjer poreznih prihoda koji se izračunava kao omjer prihoda od poreza i doprinosa i ukupnih prihoda i izdataka. Ako je vrijednost ovoga pokazatelja bliža jedan znači da se veći dio priljeva ostvaruje iz proračunskih sredstava. Međutim, za očekivati je da taj pokazatelj nikada neće biti jednak jedan, a i nemoguće je da bude veći od jedan. Zbog specifičnosti izvora financiranja pojedinih proračunskih korisnika potrebno ga je prilagoditi u ovisnosti o predmetu analize.

Stopa viška/manjka može se smatrati pokazateljem svrhovitosti kojim se ocjenjuje sposobnost proračunskog korisnika da povećava učinkovitost u smislu zadržavanja što većeg dijela raspoloživih prihoda i primitaka u obliku njihova viška. Učinkovitost je veća što je stopa veća jer u tome slučaju veći dio ostaje korisniku u smislu mogućnosti poboljšanja, povećanja i razvoja djelovanja pojedinog proračunskog korisnika. Preduvjet razvoja je ekonomično, djelotvorno i svrhovito upravljanje sredstvima i u tome smislu sposobnost proračunskog korisnika da ostvaruje viškove prihoda i primitaka kao poluge daljnjeg rasta i razvoja. U slučaju ostvarivanja manjka prihoda i primitaka stopa viška/manjka bit će ne- 
gativna te će označavati neučinkovito djelovanje proračunskog korisnika. Ako je navedena stopa nula, proračunski korisnik djeluje na granici svrhovitosti.

Prema konceptu modificirane računovodstvene osnove prihodi se priznaju u trenutku kada su naplaćeni, a oni prihodi koji nisu naplaćeni iskazuju se kao obračunati prihodi u pasivi bilance proračunskog korisnika. Obračunati prihodi mogu biti od poslovanja ili od prodaje nefinancijske imovine. Obračunati prihodi poslovanja uključuju sve vrste prihoda poslovanja (porezi, doprinosi, naknade itd.) te se zadržavaju u pasivi bilance sve do priljeva novčanih sredstava kada se klasificiraju kao prihodi poslovanja. Omjer obračunatih i naplaćenih prihoda financijski je pokazatelj kojim se mjeri koliki dio prihoda u odnosu na naplaćene prihode korisnik nije naplatio. Pokazatelj je svojevrsni indikator budućeg poslovanja i važan element u kontekstu planiranja s obzirom da će se ti prihodi naplatiti u budućim obračunskim razdobljima. Obračunati prihodi mogu se promatrati kao pokriće za manjkove prihoda i primitaka u budućim razdobljima.

\subsection{Pokazatelji kapitalnih investicija}

Pokazateljima kapitalnih investicija mjeri se stupanj ulaganja u novu i obnovu postojeće imovine. Navedena skupina predstavlja neophodni dio poslovanja za veliki broj proračunskih korisnika u smislu povećanja blagostanja stanovništva. Kapitalne investicije moraju biti realizirane na način da osiguraju financijsku stabilnost proračunskog korisnika pa se u tome smislu smatraju pokazateljima financijskog stanja (tablica 4.).

Tablica 4. Financijski pokazatelji kapitalnih investicija

\begin{tabular}{|c|c|c|}
\hline Naziv pokazatelja & Brojnik & Nazivnik \\
\hline $\begin{array}{l}\text { Stupanj obnove } \\
\text { proizvedene dugotrajne } \\
\text { imovine }\end{array}$ & $\begin{array}{l}\text { Rashodi za nabavu } \\
\text { proizvedene dugotrajne } \\
\text { imovine (42) }\end{array}$ & Proizvedena dugotrajna imovina (02) \\
\hline $\begin{array}{l}\text { Koeficijent financiranja } \\
\text { investicija u proizvedenu } \\
\text { dugotrajnu imovinu }\end{array}$ & $\begin{array}{l}\text { Rashodi za nabavu } \\
\text { proizvedene dugotrajne } \\
\text { imovine (42) }\end{array}$ & Prihodi poslovanja (6) \\
\hline $\begin{array}{l}\text { Koeficijent financiranja } \\
\text { investicija u proizvedenu } \\
\text { dugotrajnu imovinu } \\
\text { donacijama }\end{array}$ & $\begin{array}{l}\text { Pomoći iz inozemstva } \\
\text { i od subjekata unutar } \\
\text { općeg proračuna (63) }\end{array}$ & $\begin{array}{l}\text { Rashodi za nabavu proizvedene } \\
\text { dugotrajne imovine (42) }\end{array}$ \\
\hline $\begin{array}{l}\text { Stupanj otpisanosti } \\
\text { ukupne imovine }\end{array}$ & $\begin{array}{l}\text { Ispravak vrijednosti } \\
\text { neproizvedene } \mathrm{i} \\
\text { proizvedene dugotrajne } \\
\text { imovine }(019+029)\end{array}$ & $\begin{array}{l}\text { (Neproizvedena dugotrajna } \\
\text { imovina (01) - Ispravak vrijednosti } \\
\text { neproizvedene dugotrajne imovine } \\
(019))+(\text { Proizvedena dugotrajna } \\
\text { imovina (02) - Ispravak vrijednosti } \\
\text { proizvedene dugotrajne imovine (029)) }\end{array}$ \\
\hline \multicolumn{3}{|c|}{$\begin{array}{l}\text { Investiranje u novu dugotrajnu nefinancijsku imovinu } \\
\text { Dugotrajna nefinancijska imovina u pripremi }(05) \\
\text { Ukupna imovina }(0+1)\end{array}$} \\
\hline
\end{tabular}


Stupanj obnove proizvedene dugotrajne imovine financijski je pokazatelj kapitalnih investicija kojim se mjeri godišnja razina ulaganja u proizvedenu dugotrajnu imovinu u odnosu na trenutačno stanje proizvedene dugotrajne imovine. Veći koeficijent označava kapitalno-intenzivne investicije u obnovu i nabavu nove proizvedene dugotrajne imovine $\mathrm{u}$ ovisnosti o tipu proračunskog korisnika. Sličan prethodnome pokazatelju je pokazatelj investiranja u novu dugotrajnu nefinancijsku imovinu koji predstavlja ulaganja u imovinu u fazi izgradnje i pripreme za korištenje.

Koeficijent financiranja investicija u proizvedenu dugotrajnu imovinu pokazatelj je kojime se ocjenjuje koliki dio prihoda poslovanja bi bio izdvojen za nabavu i obnovu dugotrajne imovine kada ne bi bilo prihoda od prodaje nefinancijske imovine. Veći koeficijent označava intenzivniju preraspodjelu sredstava na kapitalne investicije.

Za razliku od prethodnoga pokazatelja koeficijentom financiranja investicija u proizvedenu dugotrajnu imovinu donacijama ocjenjuje se mogućnost proračunskog korisnika da novonabavljenu i obnovljenu proizvedenu dugotrajnu imovinu financira kroz pomoći i donacije, između ostaloga i iz sredstava Europske unije. Veći pokazatelj označava povoljniju situaciju. Radi se o izvoru kojega bi svaki proračunski korisnik trebao maksimizirati u kontekstu poboljšanja učinkovitosti djelovanja.

Stopa otpisanosti ukupne imovine je financijski pokazatelj kojime se mjeri umanjenje neproizvedene i proizvedene nefinancijske dugotrajne imovine proračunskog korisnika. Pokazatelj se može koristiti kao indikator potrebe obnove ili zamjene postojeće imovine novom.

\subsection{Pokazatelji likvidnosti}

Pokazateljima likvidnosti ocjenjuje se financijski položaj proračunskog korisnika u smislu kratkoročne ocjene financijskog stanja, tj. ocjena likvidnosti predstavlja jedan aspekt promatranja i ocjene financijskog stanja. Likvidnost se može ocjenjivati na više razina, od one trenutačne do tekuće likvidnosti koja se odnosi na vrijeme od jedne godine (tablica 5.). Općenito, likvidnost predstavlja sposobnost podmirivanja dospjelih obveza proračunskog korisnika.

Koeficijent trenutne likvidnosti financijski je pokazatelj sposobnosti pokrića obveza za rashode poslovanja trenutačno raspoloživim novcem u banci i blagajni na dan sastavljanja bilance. Predstavlja najkratkoročniju mjeru likvidnosti proračunskog korisnika, tj. mjeru koja se može izračunavati za svaki dan i svaki trenutak raspoloživih sredstava u banci i blagajni. Upravo u tome istaknuta je nestalnost navedenoga pokazatelja i sugestija da se nije potrebno suviše pouzdati u njega. Naime, kategorija novca u banci i blagajni izrazito je promjenljiva i u ovisnosti je o brojnim drugim čimbenicima. Vrijednost pokazatelja moguće je poopćiti na način da se izračuna za više uzastopnih razdoblja. Što je više uključenih razdoblja generalizacija je pouzdanija, a to je posebice tako ako vrijednosti pokazatelja iz razdoblja u razdoblje nisu značajno različite.

S obzirom da su proračunski korisnici obvezni u Izvještaju o obvezama objaviti iznos dospjelih obveza na datum sastavljanja godišnjih financijskih izvještaja moguće je izračunati pokazatelj sposobnosti plaćanja dospjelih obveza. Koeficijent mjeri sposobnost proračunskog korisnika da trenutačno raspoloživim novcem u banci i blagajni na datum bilance podmiri dospjele obveze. 
Tablica 5. Financijski pokazatelji likvidnosti

\begin{tabular}{|l|l|l|}
\hline Naziv pokazatelja & Brojnik & Nazivnik \\
\hline $\begin{array}{l}\text { Koeficijent trenutne } \\
\text { likvidnosti }\end{array}$ & Novac u banci i blagajni (11) & $\begin{array}{l}\text { Obveze za rashode poslovanja } \\
(23)\end{array}$ \\
\hline $\begin{array}{l}\text { Sposobnost plaćanja } \\
\text { dospjelih obveza }\end{array}$ & Novac u banci i blagajni (11) & Stanje dospjelih obveza \\
\hline $\begin{array}{l}\text { Koeficijent ubrzane } \\
\text { likvidnosti }\end{array}$ & $\begin{array}{l}\text { (Financijska imovina (1) - } \\
\text { Potraživanja za dane zajmove } \\
(13))\end{array}$ & $\begin{array}{l}\text { Obveze za rashode poslovanja } \\
(23)\end{array}$ \\
\hline $\begin{array}{l}\text { Koeficijent tekuće } \\
\text { likvidnosti }\end{array}$ & Financijska imovina (1) & $\begin{array}{l}\text { Obveze za rashode poslovanja } \\
(23)\end{array}$ \\
\hline $\begin{array}{l}\text { Koeficijent financijske } \\
\text { stabilnosti }\end{array}$ & Nefinancijska imovina (0) & $\begin{array}{l}\text { Obveze za kredite i zajmove } \\
(26)+\text { Vlastiti izvori (91)) }\end{array}$ \\
\hline $\begin{array}{l}\text { Koeficijent obrtaja financijske imovine } \\
\text { Prihodi poslovanja (6) } \\
\text { Financijska imovina (1) }\end{array}$ & \multicolumn{2}{|l}{} \\
\hline
\end{tabular}

Izvor: izrada autora.

S obzirom da su proračunski korisnici obvezni u Izvještaju o obvezama objaviti iznos dospjelih obveza na datum sastavljanja godišnjih financijskih izvještaja moguće je izračunati pokazatelj sposobnosti plaćanja dospjelih obveza. Koeficijent mjeri sposobnost proračunskog korisnika da trenutačno raspoloživim novcem u banci i blagajni na datum bilance podmiri dospjele obveze.

Koeficijentom ubrzane likvidnosti mjeri se sposobnost korisnika da brzo unovčivom imovinom podmiri svoje obveze. Kada se govori o brzo unovčivoj imovini radi se o onoj financijskoj imovini proračunskog korisnika koju bi trebalo moći u relativno kratkom roku (tri mjeseca) pretvoriti u najlikvidniji oblik imovine (novac), koji će se moći koristiti za pravovremeno podmirenje obveza o njihovome dospijeću. Zbog neobjavljivanja informacija prema kriteriju likvidnosti u bilancama proračunskih korisnika kompleksnije je pitanje utvrđivanja brzo unovčive imovine. U tome kontekstu kao brzo unovčiva imovina određena je ukupna financijska imovina umanjena za potraživanja za dane zajmove. Tako utvrđena imovina uključuje novac, financijsku imovinu u obliku vrijednosnih papira i potraživanja koja nisu zajmovi. U realnom sektoru poželjna vrijednost toga pokazatelja je minimalno jedan, a kao takva može se preslikati i na proračunske korisnike.

Koeficijent tekuće likvidnosti najobuhvatniji je i najdugoročniji pokazatelj likvidnosti koji se izračunava kao omjer financijske imovine i obveza proračunskog korisnika. Radi održavanja normalne razine likvidnosti i smanjenja rizika likvidnosti poželjno je da vrijednost koeficijenta tekuće likvidnosti bude veća od dva. Na taj način minimiziran je rizik da dovoljan iznos financijske imovine neće biti pretvoren u novac za podmirenje obveza. Međutim, prije donošenja konačnog zaključka potrebno je analizirati strukturu kratkotrajne imovine i izračunati trajanje operativnog ciklusa s obzirom da kod nekih subjekata vrijednost pokazatelja veća od dva može označavati nedovoljnu likvidnost dok kod drugih subjekata vrijednost pokazatelja manja od dva, pa čak i blizu 1, može označavati zadovoljavajuću razinu likvidnosti. 
Financijska stabilnost koncept je usklađenosti strukture imovine sa strukturom izvora imovine te se u tome kontekstu radi o pokazatelju kojime se ocjenjuje financijsko stanje. Da bi se proračunski korisnik smatrao financijski stabilnim nefinancijska imovina $\mathrm{u}$ potpunosti mora biti financirana obvezama za kredite i zajmove te vlastite izvore, što znači da vrijednost pokazatelja mora biti manja od 1. Pokazateljem se ocjenjuje koliki dio obveza za kredite i zajmove te vlastitih izvora se koristi za financiranje nefinancijske imovine.

Koeficijent obrtaja financijske imovine mjera je trajanja operativnog ciklusa proračunskog korisnika. Veći pokazatelj označava bolju sposobnost upravljanja raspoloživom financijskom imovinom u pogledu raspolaganja novčanim sredstvima, financijskom imovinom i potraživanjima. Navedeno pitanje važno je s aspekta ocjene financijskog položaja proračunskog korisnika. Veći koeficijent označava brži ciklus i u tome smislu povoljniji financijski položaj i stanje proračunskog korisnika.

\subsection{Pokazatelji zaduženosti}

Kao što je ranije istaknuto, prethodni radovi u prvi plan analize djelovanja proračunskih korisnika stavljaju ocjenu financijskog stanja koja pored financijskog položaja (ocjene likvidnosti) uključuje i ocjenu zaduženosti koja predstavlja mjeru dugoročne solventnosti. U kontekstu ocjene financijskog stanja promatra se sposobnost korisnika da podmiruje svoje ukupne obveze o njihovom dospijeću (tablica 6.).

Tablica 6. Financijski pokazatelji zaduženosti

\begin{tabular}{|l|l|l|}
\hline Naziv pokazatelja & Brojnik & Nazivnik \\
\hline $\begin{array}{l}\text { Koeficijent vlastitog } \\
\text { financiranja }\end{array}$ & Vlastiti izvori (91) & Ukupna imovina $(0+1)$ \\
\hline Koeficijent zaduženosti & Obveze (2) & Ukupna imovina $(0+1)$ \\
\hline $\begin{array}{l}\text { Koeficijent posuđenih } \\
\text { izvora }\end{array}$ & $\begin{array}{l}\text { Obveze za kredite i } \\
\text { zajmove (26) }\end{array}$ & Ukupna imovina $(0+1)$ \\
\hline $\begin{array}{l}\text { Koeficijent kamata i } \\
\text { obveza }\end{array}$ & $\begin{array}{l}\text { Rashodi od kamata } \\
\text { za primljene kredite i } \\
\text { zajmove (342) }\end{array}$ & Obveze za kredite i zajmove (26) \\
\hline $\begin{array}{l}\text { Koeficijent obveza i } \\
\text { rashoda kamata }\end{array}$ & Obveze za kamate (234) & $\begin{array}{l}\text { Rashodi od kamata za primljene } \\
\text { kredite i zajmove (342) }\end{array}$ \\
\hline $\begin{array}{l}\text { Relativna naknada na } \\
\text { dospjelu glavnicu }\end{array}$ & $\begin{array}{l}\text { Rashodi od kamata } \\
\text { za primljene kredite i } \\
\text { zajmove (342) }\end{array}$ & $\begin{array}{l}\text { Izdaci za otplatu glavnice } \\
\text { primljenih kredita i zajmova } \\
\text { (54) }\end{array}$ \\
\hline $\begin{array}{l}\text { Stupanj povećanja zaduženosti } \\
\text { Primici od zaduživanja (84) } \\
\text { Obveze za kredite i zajmove (26) }\end{array}$ & \\
\hline
\end{tabular}

Izvor: izrada autora.

Koeficijentom vlastitog financiranja i koeficijentom zaduženosti ocjenjuje se zaduženost proračunskog korisnika sa statičkog aspekta te zajedno promatrano koeficijenti daju 
informaciju o strukturi pasive bilance. Koeficijentom vlastitog financiranja mjeri se koliki dio ukupne imovine je financiran vlastitim izvorima financiranja, a koeficijentom zaduženosti ocjenjuje se koliki dio ukupne imovine proračunskog korisnika je financiran tuđim izvorima financiranja. Koeficijenti vlastitog financiranja i zaduženosti u zbroju trebaju dati jedan.

Precizniji pokazatelj analize tuđih izvora financiranja je koeficijent posuđenih izvora. Koeficijent posuđenih izvora prikazuje koliki dio ukupne imovine se financira iz obveza za kredite i zajmove, tj. koliki dio imovine je financiran kamatonosnim obvezama. Koeficijent posuđenih izvora uvijek je manji od koeficijenta zaduženosti, a ako su ta dva pokazatelja jednaka to znači da proračunski korisnik nema drugih obveza osim obveza za kredite i zajmove.

Financijskim pokazateljem koeficijent kamata i obveza mjeri se koliki dio obračunatih kamata čine obveze za kredite i zajmove. Pokazatelj se izračunava kao omjer obračunatih rashoda od kamata za primljene kredite i zajmove u promatranoj godini te ukupnog stanja obveza za kredite i zajmove na kraju promatrane godine. Iako se s jedne strane u brojniku nalazi teret korištenja tuđeg kamatonosnog kapitala u određenoj godini, a u nazivniku se nalazi dio obveza za taj tuđi kapital koji će dospijevati idućih godina, navedeni pokazatelj može biti svojevrsni indikator koštanja korištenja tuđih kamatonosnih izvora financiranja s obzirom da se radi o godišnjim iznosima rashoda na postojeće obveze koje su umanjene za već otplaćeni dio glavnice. U tome smislu, može se reći da je pokazatelj svojevrsni 'worst case scenario' te da je stvarna kamatna stopa na dug zapravo manja.

Koeficijent obveza i rashoda kamata izračunava se kao omjer obveza za kamate te rashoda od kamata za primljene kredite i zajmove. Rashodi od kamata obračunavaju se u razdoblju na koje se odnose te se u tome trenutku evidentiraju kao rashod, iako sama isplata može uslijediti u kasnijem trenutku pa se do trenutka isplate te kamate evidentiraju kao obveze. Sukladno temeljima modificirane računovodstvene osnove, koju obvezno primjenjuju proračunski korisnici, za razliku od prihoda koji se priznaju onda kada su i naplaćeni, rashodi poslovanja priznaju se primjenom načela nastanka događaja u izvještajnom razdoblju u kojemu su i nastali neovisno o tome jesu li u tome izvještajnom razdoblju i isplaćeni. Koeficijentom obveza i rashoda od kamata mjeri se koliki dio obračunatih rashoda od kamata $u$ promatranome obračunskom razdoblju nije plaćen.

Obračunati rashodi od kamata tijekom jednog obračunskog razdoblja usko su povezani s isplaćenim iznosima glavnice toga obračunskog razdoblja te u zbroju predstavljaju anuitete. Ovisno o modelu obračuna kamata na primljene zajmove i kredite ovisi njihov udio u otplatnim kvotama koje također ovise o modelu otplate. Relativna naknada na dospjelu glavnicu predstavlja pokazatelj kojime se ocjenjuje koliki dio isplaćene glavnice primljenih kredita i zajmova pojedinog razdoblja čine rashodi od kamata toga obračunskog razdoblja. U zbroju, rashodi od kamata i izdaci za otplatu glavnice primljenih kredita i zajmova, predstavljaju sumu obračunatih i u pravilu isplaćenih anuiteta pojedinog obračunskog razdoblja.

Stupanj povećanja zaduženosti izračunava se kao omjer primitaka od zaduživanja i obveza za kredite i zajmove te prikazuje udio novonastaloga duga u pojedinom obračunskom razdoblju u ukupnim postojećim obvezama za kredite i zajmove krajem toga obračunskog razdoblja. Stupnjem povećanja zaduženosti moguće je mjeriti dinamiku promjena strukture tuđih izvora financiranja u kontekstu cjelokupne ocjene zaduženosti. 


\section{ZAKLJUČAK}

Cilj djelovanja proračunskih korisnika je namjensko trošenje javnih (proračunskih) sredstava na učinkovit, odgovoran i transparentan način. Kako bi se osiguralo da proračunski korisnici djeluju u skladu s navedenim načelima potrebno je njihovo vrednovanje. Određenu ulogu u tome kontekstu imaju mehanizmi interne i državne revizije. Ocjena djelovanja proračunskih korisnika u sustavu suvremenog proračunskog upravljanja mora biti usmjerena procjeni razine učinkovitosti, odgovornosti, transparentnosti i integriteta. U tome smislu, moguće je primjenjivati različite tehnike, a koje uključuju ocjenu kvalitativnih i kvantitativnih aspekata djelovanja. Dok je procjena odgovornosti, transparentnosti i integriteta u pravilu ograničena na kvalitativne i nefinancijske podatke, značajnu ulogu u ocjeni učinkovitosti imaju upravo financijski podaci dostupni iz računovodstvenog sustava i financijskih izvještaja proračunskih korisnika. Primjenom specifičnih financijskih pokazatelja moguće je ocjenjivati ekonomičnost, djelotvornost, svrhovitost, financijski položaj i stanje te donositi zaključke o ukupnoj učinkovitosti proračunskih korisnika. Kao polazište za istraživanje cilja rada koji uključuje oblikovanje financijskih pokazatelja za proračunske korisnike korištena je relevantna literatura usmjerena analizi djelovanja subjekata u javnom sektoru, općenita znanja o analizi financijskih izvještaja te spoznaje o specifičnostima proračunskog računovodstva u Republici Hrvatskoj kao važne odrednice financijskog izvještavanja proračunskih korisnika. Provedeno istraživanje rezultira s pet skupina financijskih pokazatelja usmjerenima ocjeni financijskog stanja i položaja te učinkovitosti djelovanja proračunskih korisnika. Za ocjenu financijskog položaja te dugoročnije financijskog stanja, dan je prijedlog 18 pojedinačnih financijskih pokazatelja podijeljenih u skupine kapitalnih investicija, zaduženost i likvidnost. S obzirom da proračunski korisnici u svome djelovanju moraju biti učinkoviti, u radu je dan prijedlog 10 pojedinačnih financijskih pokazatelja kojima se ocjenjuje djelotvornost, ekonomičnost i svrhovitost upravljanja javnim sredstvima.

\section{LITERATURA}

1. Bejaković, P., Vukšić, G. Bratić V. (2011.) Veličina javnog sektora u Hrvatskoj. Hrvatska i komparativna javna uprava, 11(1), 99-125., 108.

2. Brown, K. W. (1993.). The 10-Point Test of Financial Condition: Toward an Easyto-Use Assessment Tool for Smaller Cities, Government. Finance Review, 21-216. available at: https://lgc.uwex.edu/files/2016/04/kenneth-brown-Ten-point-test.pdf [05/03/2017].

3. Gibson, C. H. (2011.) Financial Statement Analysis. 12th ur. Canada: South-Western, Cengage Learning.

4. Government Accounting Standards Board. An Analyst's Guide to Government Financial Statements, Dean Michael Mead, GASB, 2001.

5. Hladika, M., Žigman, A. (2012.) Financijski pokazatelji za ocjenu poslovanja neprofitnih organizacija. Riznica, Zagreb: Hrvatska zajednica računovođa i financijskih djelatnika, 2012(2), 25-29. 
6. Institut za javne financije - IJF (2009.) Proračunski vodič za građane. drugo, promijenjeno izdanje dostupno na: http://www.ijf.hr/proracunski/2009.pdf [datum: 05/03/2018].

7. Institut za javne financije. Pojmovnik javnih financija. dostupno na: http://www.ijf.hr/ hr/korisne-informacije/pojmovnik-javnih-financija/15/proracun/266/transparentnostproracuna/267/ [datum: 06/03/2018].

8. International Monetary Fund (2014.) Government Finance Statistics Manual, available at: https://www.imf.org/external/Pubs/FT/GFS/Manual/2014/gfsfinal.pdf [datum: 06/03/2018].

9. Kablan, A. (2013.) Financial Statement Analysis in Municipalities and an Application. International Journal of Research in Business and Social Science, 2(3), 75-86.

10. Međunarodna organizacija vrhovnih revizijskih institucija (INTOSAI). Međunarodni standardi vrhovnih revizijskih institucija (ISSAI). ISSAI 300 Temeljna načela revizije učinkovitosti. dostupno na: http://www.revizija.hr/datastore/filestore/52/ISSAI_300. pdf [datum: 06/03/2018].

11. OECD (2015.) Public Governance \& Territorial Development Directorate. Public Governance and Territorial Development Directorate. Recommendation of the Council on Budgetary Governance. availabel at: http://www.oecd.org/gov/budgeting/Recommendation-of-the-Council-on-Budgetary-Governance.pdf [datum: 06/03/2018].

12. OECD (2017.a) OECD Recommendation of the Council on Public Integrity. available at: http://www.oecd.org/gov/ethics/Recommendation-Public-Integrity.pdf [datum: 06/03/2018].

13. OECD (2017.b) Public Governance Directorate. Budget Transparency Toolkit. Practical steps for supporting openness, integrity and accountability in Public Financial Management. Developed by the OECD with the participation of the Global Initiative for Fiscal Transparency (GIFT) Network. available at: http://www.oecd.org/gov/budgeting/Budgeting-Transparency-Toolkit.pdf [datum: 06/03/2018].

14. Palepu, K. G., Healy, P. M., Bernard, V. L. \& Peek, E. (2007.) Business Analysis and Valuation: IFRS Edition - Test and Cases. London: Thomson Learning.

15. Penman, S. (2009.) Financial Statement Analysis and Security Valuation. 4th ur. New York City: McGraw-Hill/Irwin.

16. Pravilnik o financijskom izvještavanju u proračunskom računovodstvu, Narodne novine, br. 3/2015., 135/2015., 2/2017., 28/2017. dostupno na: https://narodne-novine. nn.hr/clanci/sluzbeni/2015_01_3_59.html [datum: 06/03/2018].

17. Pravilnik o proračunskom računovodstvu i računskom planu, Narodne novine, br. 124/2014., 115/2015., 87/2016., 3/2018., dostupno na: https://narodne-novine.nn.hr/ clanci/sluzbeni/2014_10_124_2374.html [datum: 06/03/2018].

18. Pravilnik o unutarnjoj reviziji u javnom sektoru, Narodne novine, broj 42/2016. dostupno na: https://narodne-novine.nn.hr/clanci/sluzbeni/2016_05_42_1092.html [datum: 06/03/2018].

19. Ramsey, T. K. (2013.) Measuring and Evaluating the Financial Condition of Local Government. A Thesis. The Faculty of the Department of Public Policy and Administration California State University, Sacramento, Master of Public Policy and Administration. 
20. Reck, J., Lowensohn, S. i Wilson, E. (2016.) Accounting for Governmental \& Nonprofit Entities. Chapter 10: Analysis of Governmental Financial Performance, $17^{\text {th }}$ Edition, McGraw Hill Education, 409-410.

21. Robinson, T. R., Van Greuning, H., Henry, E. \& Broihahn, M. A. (2009.) International Financial Statement Analysis. New Jersey: John Wiley \& Sons, Inc.

22. Roje, G. (2008.). Elementi i pokazatelji financijskog položaja države - osvrt na međunarodna iskustva. Riznica, Zagreb: Hrvatska zajednica računovođa i financijskih djelatnika, 2008(2), 28-31.

23. Sever, S., Žager, L. (2008.). Analiza financijskih izvještaja kao instrument kontrole u javnom sektoru. Hrvatski javni sektor - praksa i perspektive, Zagreb-Opatija (ur. Vašiček, D.), Zagreb: Hrvatska zajednica računovođa i financijskih djelatnika, 434-443.

24. Suarez, V., Lesneski, C. i Denison, D. (2011.) Making the Case for Using Financial Indicators in Local Public Health Agencies. Am J Public Health, 101(3), 419-425.

25. Subramanyam, K. R. \& Wild, J. J. (2009.) Financial Statement Analysis. 10th ur. New York: McGraw-Hill/Irwin.

26. The Canadian Institute of Chartered Accountants (CICA) (1997.) Indicators of Government Financial Condition, available at: https://www.gnb.ca/oag-bvg/2001/chap2e. pdf [datum: 05/03/2017].

27. The International City/County Management Association's (ICMA) (2003) Evaluating Financial Condition: A Handbook for Local Government, 4th edition, Intl City County Management Assn (ISBN-13: 978-0873261357)

28. The Public Sector Accounting Board (PSAB) (2010). Statements of Recommended Practice (SORP) 4: Indicators of Financial Condition, available at: https://oag-ns.ca/ sites/default/files/publications/2010\%20-\%20Nov\%20-\%20Ch\%2006\%20-\%20Indicators\%20of\%20Financial\%20Condition.pdf [datum: 05/03/2017].

29. Wahlen, J. M., Baginski, S. P. \& Bradshaw, M. T. (2011.) Financial Reporting, Financial Statement Analysis, and Valuation: A Strategic Perspective. 7th ur. Mason: South-Western Cengage Learning.

30. Zakon o državnom uredu za reviziju, Narodne novine, broj 80/2011., dostupno na: https://narodne-novine.nn.hr/clanci/sluzbeni/2011_07_80_1701.html [24/05/2018].

31. Zakon o proračunu, Narodne novine, broj 87/2008., 136/2012., 15/2015. dostupno na: https://narodne-novine.nn.hr/clanci/sluzbeni/2008_07_87_2791.html [datum: 06/03/2018].

32. Zakon o sustavu unutarnjih kontrola u javnom sektoru, Narodne novine, broj 78/2015., dostupno na: https://narodne-novine.nn.hr/clanci/sluzbeni/2015_07_78_1492.html [datum: 06/03/2018].

33. Žager, K., Mamić Sačer, I., Sever Mališ, S., Ježovita, A., Žager, L. (2017.). Analiza financijskih izvještaja: načela, postupci, slučajevi. (treće izmijenjeno i dopunjeno izdanje). Zagreb: Hrvatska zajednica računovođa i financijskih djelatnika. 